\title{
Stakeholder collaboration inspired by the Nordic model: Towards sustainable work and competitiveness during an industrial start-up
}

\author{
Ulrika Harlin \\ Martina Berglund \\ Katrin Skagert \\ Mattias Elg
}

\section{Abstract}

External stakeholder collaboration is vital for new industrial projects and establishments. The aim of this paper is to explore why and how new firms can create relations and stakeholder collaboration with trade unions during industrial start-ups. A case study was carried out in the early phases of a new firm's major greenfield project aimed at establishing a new industrial domain in a Nordic context. The results showed that early co-operation between a new firm and trade unions has the potential to proactively address prerequisites for sustainable work in design phases of new factories, but also to strengthen the attention to other dimensions of social sustainability that are crucial for an industrial start-up's longterm possibilities for success. However, specifically in a rapidly growing new firm, there needs to be a systematic approach that incorporates continuous anchoring activities both within and between the stakeholders. Practical implications are how new firms can initiate and establish co-operation with trade unions and other social partners in fast-moving work environments and change processes. Hence, the study identifies advantages and approaches for new firms to build relations with trade unions in a stakeholder collaboration chain inspired by the Nordic model. Further, to proactively pay attention to dimensions of social sustainability in a new firm's early development phases and change processes, such as industrial start-ups, seems beneficial from an individual, business, and a societal perspective.

Keywords: Entrepreneurship, high-growth, social sustainability, trade union co-operation, production system development 


\section{Introduction}

Research emphasises that collaboration and establishing relationships with external stakeholders are vital in development phases of a business, because they create an innovative environment, with a collective ability to take proactive action and to respond to opportunities (Akerhurst et al., 2009; Tripathi et al., 2019). Stakeholders collaborating in an industrial start-up context can also be regarded as regional intermediaries, with an important role of forming shared innovation strategies between the actors, and attracting anchor tenants to the region (Smedlund, 2006). Thus there is potential for fruitful synergies and successful realisation of plans, by way of collaborations between interdependent actors and stakeholders in entrepreneurial communities, such as new firms and industrial start-ups (Audretsch et al., 2011).

Crucial elements for achieving sustainable change processes are three-party collaboration between the government, companies, and unions, as identified in a Scandinavian context (Brulin \& Svensson, 2016). However, there is a gap in the literature on stakeholder collaboration that is focussed on sustainable work during industrial start-ups (Harlin \& Berglund, 2020). Some obstacles for operationalisation of sustainable work dimensions (as part of social sustainability) during industrial development phases are that these dimensions are fuzzy and not clearly defined (Vallance et al., 2011). Other obstacles are that there might initially be a lack of internal knowledge to design and realise future plans in young companies with a high density of entrepreneurs (Davila et al., 2010). Previous research describes how collaboration with external stakeholders such as trade unions may fill this gap, and contribute to jointly identifying potential problems, finding solutions, making decisions better rooted among employees and enabling organisations to implement challenging decisions (Levinson \& Wallenberg, 2006; Levinson 2008). Other advantages of trade union co-operation in early development phases are possibilities of increased knowledge and understanding of "what really works" and early anchoring amongst a wider workforce (Totterdill et al., 2016). In a Swedish context, specifically the co-operation between industrial organisations and social partners is beneficial (Zellman \& Kemp, 2004). Several researchers have taken an interest in the Nordic model related to work, which is characterised by a comprehensive collective agreement system, employee participation in development phases, systems for improving the working environment, and collaboration between organisations and social partners (Nielsen et al., 2012). Additionally, early trade union collaboration in decision processes are found valuable by management and has the potential to increase employee participation in change processes (Kjellberg, 2011). However, previous research on industrial trade union collaboration focusses mostly on daily operations in established organisations, and less on collaboration during radical changes (Rydell, 2015). In an increasing industrial pace of change, it is increasingly important to consider this from a work perspective, where Johansson \& Abrahamsson (2009) stress that new industrial contexts create new prerequisites and new opportunities for development. Thus, a question raised in this paper is the potential and conditions for new firms during industrial start-ups to establish relations and collaborations with trade unions in very early phases. By studying an industrial start-up (a new firm's greenfield project in its early development phases), the aim of this paper is to explore why 
and how new firms can create relations and stakeholder collaboration with trade unions during industrial start-ups.

\section{Literature overview}

\section{Stakeholder collaboration in an industrial start-up ecosystem}

In the context of "start-up ecosystems", e.g., organisations that collaborate to support a startup in a region (Tripathi et al., 2019), the early establishment of relationships between stakeholders is found to be crucial. Entrepreneurship literature further emphasises the importance and the advantages of nascent firms' collaboration with stakeholders, and of building relationships that enable synergies (Audretsch et al., 2011; Bank et al., 2017; Volkmann et al., 2019). Research also emphasises the potential in learning from different sources, where collaboration and building long-term relationships between stakeholders, such as enterprises, social partners, researchers, policymakers, and consultants, may create "joint intelligence" (Totterdill, 2015). This is also supported by studies of stakeholder collaboration in entrepreneurial contexts, where there is the potential to create win-wins for participating stakeholders and a positive learning process for all involved (Klofsten \& Lundmark, 2014).

External stakeholders may co-operate for different purposes during start-up, with potential to support acceleration of the start-up, and of the new firm's overall business and innovation strategy (Kohler, 2016). For example, stakeholder collaboration may enable the preconditions for innovation capability, the ability to jointly identify and respond to opportunities (Akehurst et al., 2009), and successful workplace innovation (Totterdill, 2015). Hence, depending on the jointly focussed development area related to a firm's change process and desired outcome, this collaboration needs to be carried out at different levels such as local, regional, and national levels (DiVito \& Ingen-Housz, 2019).

To achieve the desired outcomes of stakeholder collaboration, research emphasises approaches and prerequisites that need to be considered. Influencing factors are the composition of actors in the network and their interrelationships (Elfring \& Hulsink, 2003). The maturity of an organisation also needs to be considered where there may be different prerequisites for parties who co-operate regarding structures, dynamics, and experience (Kohler, 2016). Studies carried out in entrepreneurial programmes also pinpoint that an aspect that needs to be taken into consideration is that it may take time for new entrepreneurial businesses to build and establish a collaboration system (Klofsten \& Lundmark, 2014). They also identify that the roll-out and replicability, e.g., the transfer from the initiating organisation, is efficient once there is a receiving stakeholder with assigned tasks and resources. Furthermore, enabling success factors are that the process is supported by a programme manager, coach or workshop leader with practical experience within the domain, and that it is important that the intended process is supported in three ways: internally within the organisation, externally among stakeholders, and also from participants joining the 
process (Klofsten \& Lundmark, 2014). Hence, a systematic approach in a collaboration programme is required, with consideration of design parameters such as: proposition (i.e., the purpose and what the collaboration offers); the process (i.e., how it is run); people (i.e., who needs to be involved); and place (i.e., where the collaboration is carried out) (Kohler, 2016).

As a new firm's stakeholder collaborations during change processes such as industrial startups are influenced by several factors, it is also vital to consider key elements and to gain understanding of mechanisms that affect sustainable change.

\section{Approaches for sustainable change processes}

The notion of sustainable change can be characterised by two interrelated perspectives of content and process, and studies of change need to be related to the specific context (Pettigrew, 2012). A content perspective entails a view of sustainable change characterised by a balance between a result orientation (in terms of effectiveness, economic growth or innovation) and good working conditions (in terms of health, gender equality, learning and development) (Elg et al., 2015). Its focus is in line with the idea that efforts striving toward sustainable development must handle and balance different, sometimes conflicting needs that may be associated with a change process. In practice, at the point of departure, enablers for realising a change process "from visions to action" need to consider ethics and values, consensus of the aim, the stakeholders' roles as well as the management system for the mission (Svensson \& Brulin, 2014; Svensson et al., 2013). In a process perspective, sustainability is about the mechanisms that lead to long-term effects of development efforts in organisations. The way that change is carried out thus has immediate and direct consequences for the probability of successful change. Static and programmatic ways of organising for sustainable change often lead to failures. Instead, change is viewed as an open process of learning, and mutual adaptation between different actors and perspectives (March, 1981; Beer et al., 1990; Brulin \& Svensson, 2016).

Furthermore, Svensson and Brulin (2014) have identified three elements promoting sustainable change processes: i) active ownership; ii) broad collaboration in partnerships; and iii) developmental learning, as illustrated in Figure 1. 


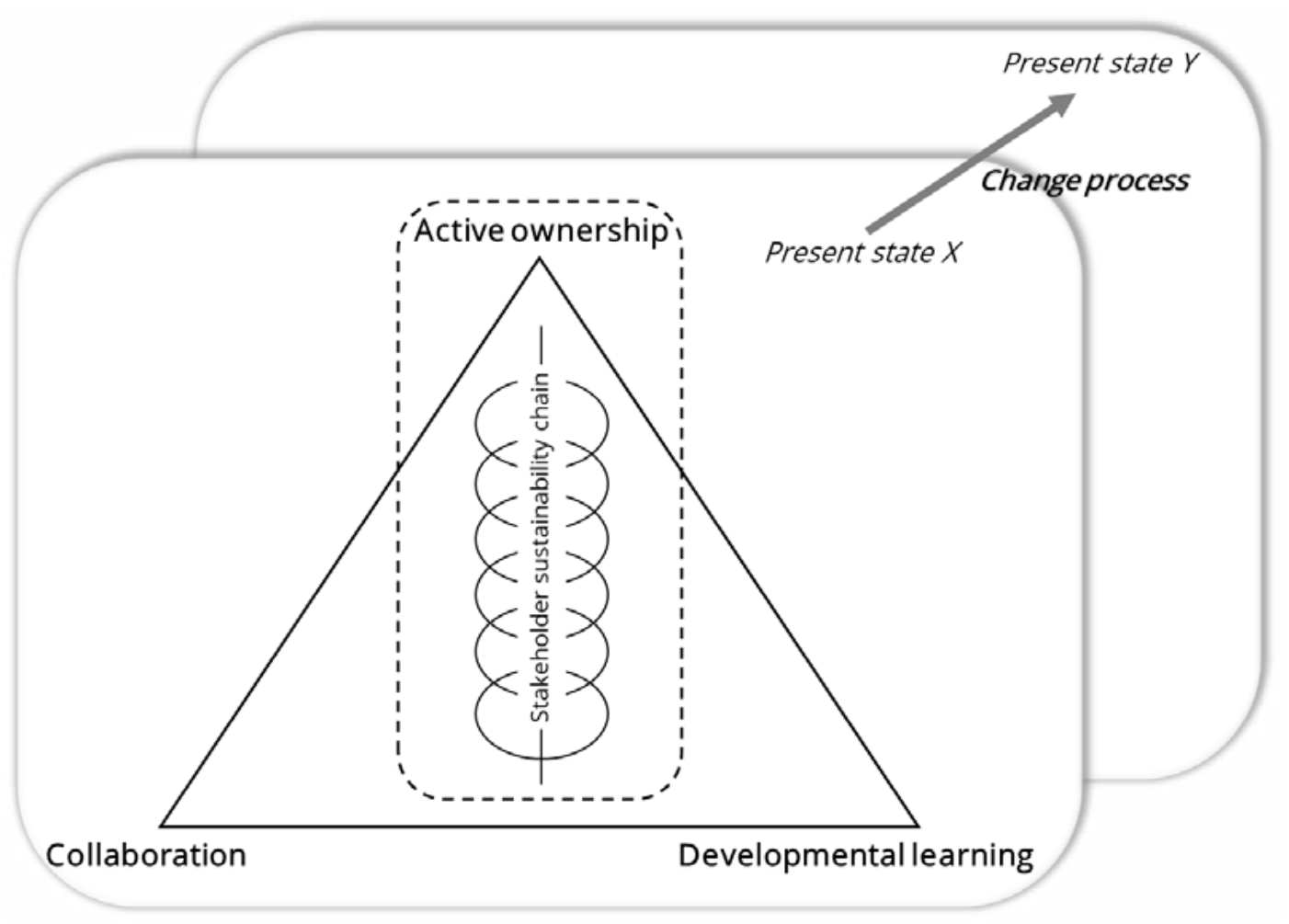

Figure 1. Mechanisms for sustainable development of stakeholder collaboration and longterm effects of change processes.

The "stakeholder sustainability chain", a part of active ownership, illustrates interconnections between stakeholders in change processes (modified from Svensson and Brulin (2014).

There is broad consensus that change efforts often fail due to lack of ownership. The mechanism that knits this together is the first element, active ownership. It directs attention to the various roles and engagements that owners of projects and programmes as well as stakeholders. must pursue, as illustrated in the "stakeholder sustainability chain", Figure 1. For example, a project organisation that considers and balances perspectives of different stakeholders may lead to more sustainable development in different types of change processes over time, e.g., improvement and development work (from a present state $\mathrm{X}$ to $\mathrm{a}$ new present state $Y$ ). Thus, if a part of the chain breaks, the prerequisites for sustainable development may also fail. Furthermore, the second element, collaboration, enables broad inclusion of actors in partnerships, where the robustness and anchoring of change are secured. The third element, developmental learning, is the ability to utilise learnings initiated from disruptions or new challenges requiring new approaches or rethinking (Ellström, 2010; Svensson \& Brulin, 2014).

\section{Characteristics of the Nordic model related to work}

The basic idea of the Nordic model related to work is trade union collaboration at workplaces and that a firm's stakeholders share a common vision that it will create a "win-win" situation, i.e., lead to positive effects for both employees and employers (Huzzard \& Nilsson, 2004). 
Previous studies witness that employee participation in early phases of radical change processes enable prerequisites for an offensive and solution-oriented collaboration in a longterm perspective that considers interests from both employees and employers (GarmannJohnsen et al., 2018). Furthermore, trade union collaborations related to competence and workplace-related issues may contribute to competitive advantages, as it may counteract employees' contradictions and instead create drivers for engagement both in daily work and during change processes (Kjellberg, 2011). Thus, Nordic approaches for workplace-based developments with a high degree of employee participation in development efforts (Sarfati, 2014) deserve reflection by new firms and industrial start-ups. This also applies to the process of achieving collective agreements between employers and employees, which is at the core of this arrangement (Nielsen et al., 2012). There are challenges, however, and the literature tells of both perceived negative and positive impacts of trade union collaboration at workplaces based on the Nordic model. Experiences of trade union collaboration from other countries or organisations found it pessimistic and conflict-oriented, and created limitations (Geary \& Trif, 2011). On the other hand, other literature highlights improved possibilities to implement difficult decisions, perceived working climate, increased productivity, increased flexibility, improved job security and increased employee influence (Geary \& Trif, 2011; Glover et al., 2014). Furthermore, the increasing speed of change increases the need of innovative activities in stakeholders' collaborations that promote both development of sustainable work, as well as flexibility and efficiency (Hasle, 2014).

\section{Research methodology}

A case study with an interactive research process approach was carried out at a new firm during the start-up firm's trade union collaboration process in early development phases of planned production facilities. The study ran for 26 months. In frequent collaboration, the assigned researcher, practitioners from the start-up firm and external stakeholders, i.e., members representing three trade union organisations in the firm's working councils, interacted throughout the whole research process. All had the opportunity to contribute to an interpretation of the research object, and common conceptualisation, based on the model for "interactive research approach" (Nielsen \& Svensson, 2006; Svensson et al., 2007). This approach is characterised by "recurrent interactions and joint learning activities between researchers and practitioners, in commonly agreed efforts to study change and innovation in organisations" (Ellström et al., 2020). It has similarities to the Norwegian tradition of action research with the specific aim of developing workplaces in a healthy, participatory and productive way (Hilsen \& Kværne, 2020). However, it differs in that the role of the researcher is to focus on joint learning and knowledge creation, rather than having a driving role in the practical development work (Ellström et al., 2020).

In this case, the start-up firm took the initiative for the research collaboration, and participated in initial phases to jointly formulate the scope and research approach. A steering group for the research project was formed consisting of a representative from the new firm, 
the funding organisation and the researcher. Due to the high degree of confidentiality, there was an agreement on how to document, store and manage data.

\section{The case study}

The case in this paper was part of a research project with an overall objective to contribute to knowledge about establishment of a new industrial domain, i.e., a new firm 's start-up with a mission of development and large-scale production of products and sustainable solutions for energy storage in Europe, with start in Sweden. It was regarded as a unique greenfield project carried out at a fast and demanding pace, and considered one of the most important industrial investments, with high ambitions to accelerate the pace of transition towards electrification, thus contributing to European climate goals and a fossil-free society. The firm had a strategic sustainability approach, initially focusing on dimensions of economic and environmental sustainability. However, insights grew during the first year in the high-growth firm of also paying attention to sustainable work dimensions, a part of social sustainability. Consequently, as reflected on in this paper, they initiated a stakeholder collaboration process with three relevant trade union parties (i.e., social partners) in the early phases of the startup, where the overall purpose was to proactively create conditions for development of a world-class concept for working conditions and work organisation in future production facilities, and to become a member in an employer association that supported the initial collective agreement process.

The main purpose of the part of the case study reported in this paper was on key learnings from the new firm's collaboration with social partners such as trade unions. The unit of analysis in this study was the new firm 's stakeholder collaboration process with trade unions during the industrial start-up, i.e., during the early development phases and emerging growth of the new firm. The new firm is referred to as the co-operation unit.

\section{Data collection and analysis}

The case study focussing on the new firm's stakeholder collaboration with trade unions started one year and three months after the official launch of the new firm, and was carried out during the following 26 months. Data collection was mainly conducted through observations at the start-up firm's trade union meetings. Data was also collected through open interviews with representatives from three trade unions, and documentation studies from the meetings. The researcher observed 21 working council meetings with opportunities to interact by way of presentations and dialogue regarding sub-results from the case study, and documentation of the trade union collaboration process, see Table 1. 
Table 1. Data collection - meetings

\begin{tabular}{lc}
\hline $\begin{array}{l}\text { Working council meetings } \\
\text { Participants: Representatives from the new firm and trade unions }\end{array}$ & $\begin{array}{c}\text { No. of } \\
\text { meetings }\end{array}$ \\
\hline Central Working Council (Company group) & 8 \\
\hline Regional Working Council (Factory A) & 6 \\
\hline Regional Working Council (Factory B) & 5 \\
\hline Overall stakeholder meeting (all working councils represented) & 2 \\
\hline Total & $\mathbf{2 1}$
\end{tabular}

The formal trade union collaboration was carried out in the new firm's working council meetings. The external stakeholders represented three trade union organisations at a central level of the firm (Central Working Council), and as the firm approached construction and industrialisation phases of the two factories in two different regions, two Regional Working Councils (Factory A and Factory B) were also initiated and established. The process leader and the manager of "growth and culture" in the new firm were drivers of the process, and links between stakeholders in the different working councils. During all the trade union meetings, the process leader was the chairman, and the researcher of the case study the secretary, documenting the minutes of the meeting. After each meeting, the meeting minutes were verified and validated in two steps, first by the firm's manager of the union collaboration process and the process leader, and then by those in attendance at the meetings. This was the first point on each union meeting agenda. Additionally, data was collected by observations at 24 internal preparation and follow-up meetings in the new firm, and regularly from open interviews with the process leader. Data collection also included five open interviews carried out with the union stakeholders, as well as studies of firm documents, primarily PowerPoint presentations and internal meeting minutes. This case study was part of a larger research project with a mission to follow-up learnings from a start-up in early phases, hence, a new firm's major greenfield project within a new industrial domain, as reported in Harlin and Berglund (2020).

The identified elements which constituted mechanisms for sustainable development of change processes, as described by Svensson and Brulin (2014), were regarded as relevant to consider in a change process such as an industrial start-up carried out by a new firm, i.e., where collaborations between a new firm and external stakeholders are vital to create conditions to support scale-up and growth at a fast pace, and thus used in a thematic analysis in this paper. 


\section{Findings}

\section{The context: Point of departure and drivers for the collaboration process between the new firm and trade unions}

In an early dialogue between top management and an expert in industrial and stakeholder relations, the new firm learned of the importance of strengthening the approaches regarding the social dimensions of sustainability related to sustainable work, in parallel with economic and ecological dimensions, which was on the new firm's strategic agenda. A trigger for starting a co-operation with trade unions was a reflection from an external stakeholder that the new firm "was strategic and clear about sustainability from an external perspective, but not as clear on how to address sustainability and sustainable development within the firm, that is from a human perspective". Consequently, to strengthen competences related to sustainable work, and create strategic relations and processes to support establishment of the new firm and its major start-up within a new industrial domain, an expert, also a former executive chairman of a large trade union organisation, was assigned as an internal process leader. This was the starting point for the new firm's process of establishing a collaboration with social partners, e.g., relevant employee organisations (trade unions) and one employer association.

As described before, the point of departure of the case study was one year and three months after the official launch of the new firm. During this time period, the new firm's project organisation initially planned for two factory establishments: Factory $A$, a test and industrialisation factory requiring 200 to 300 employees in one region, and Factory $B$, a largescale factory (requiring approximately 2500 employees) in another region. Factory A was crucial as a model for the first large-scale factory, but also for potential forthcoming factories in other regions and countries. Hence, the new firm planned for extensive growth during the coming years, and at the start of this case study there were 110 employees and over 20 nationalities, with new employees hired by the firm every week. After 26 months (at the end of the case study), the firm had grown to over 700 employees from over 70 nationalities, representing a wide range of countries and fields, with experience from several branches worldwide.

An executive entrepreneur, who also was part of the top management team, was appointed to develop the new firm's growth, and to build a strong company culture in parallel with managing daily operations in the fast-growing firm. This included developing a conceptual model of a forthcoming production work organisation, enabling rapid decision-making, efficient onboarding, learning and competence development in an evolving organisation beyond national borders. The two founders of the firm had previous experience of rapid, large-scale industrial start-ups, and expressed that they wanted to merge experienced advantages in practice with strengths of European models for culture and work organisation. Specifically, the study showed that reasons for the new firm's initiating relations and 
collaboration with stakeholders such as trade unions were their efforts to learn from the Nordic approach related to industrial work, as expressed by one of the founders:

«Our ambition is to build on the European model of utilising success factors from other industrial working cultures. »

«The relationship between companies and unions is unique in Sweden. It is a unique advantage. Both how the unions are genuinely interested in the company doing well, and for employment conditions. »

Furthermore, the new firm's drivers for initiating collaboration with trade unions in its early development were to create prerequisites "to build right from scratch", to gain support to proactively manage potential obstacles related to work and culture during the fast pace of the firm's growth, and to develop a replicable conceptual model for industrial workplaces and future factories.

On the other hand, reasons for trade unions to initiate relations in an early co-operation process with the new firm already during start-up were illustrated in the following quotes:

«This firm is unique because it's a huge business ambition that doesn't really exist yet. It is particularly interesting because you have to grow big and need capability to handle many things quickly. It's not every day that we are involved in creating a new industrial domain with new factories in Sweden. »

«Being involved in building companies from scratch can create many different values, it can work right from the start. »

«As a trade union representative, it's about being a mediator in solution-oriented problem-solving. We want to be involved in creating this industrial journey - with great participation. »

«If you build good relationships with trade unions, it will be easier when complexity increases. »

Both the new firm and the trade unions expressed that the aim for collaboration was to jointly contribute to the success and competitiveness of the new firm, and to strengthen the firm's possibilities for a successful start-up and establishment of factories within a new industrial domain in a Swedish context.

These drivers were commonly agreed upon and initially described in a "Declaration of Purpose for Collaboration" (DoP) with the three relevant trade unions: 
«The purpose of the co-operation (as described with this Declaration of Purpose), is to contribute long-term to the success and competitiveness of the start-up firm as well as to develop a world-class concept for future manufacturing sites. »

More specifically, the aim was to create prerequisites to design "the best future industrial workplaces", demonstrating flexibility, power of innovation and excellent manufacturing results.

\section{The process: Building collaboration with social partners during the new firm's industrial start-up}

The new firm built up the collaboration with social partners, e.g., three relevant trade union organisations, and became a member of an employer association. As described previously, the firm recruited the expert within industrial relations as a process leader, with the mission to create relationships with trade unions and furthermore to structure and develop fruitful co-operation striving for outcomes enabling sustainable work and competitive advantages for the new firm. The new firm's very early stakeholder collaboration approach with social partners was considered unique and innovative by all involved parties. Table 2 summarises the parties and representatives who were involved in stakeholder collaboration in the early phases of the new firm development and industrial start-up.

Table 2. Stakeholders in collaboration

\begin{tabular}{lll}
\hline Stakeholders & Central Working Council & $\begin{array}{l}\text { Two Regional Working Councils: } \\
\text { Factory A and B }\end{array}$ \\
\hline The new firm & $\begin{array}{l}\text { Representatives from the } \\
\text { company group. } \\
\text { (Top management, human } \\
\text { resource management, process } \\
\text { leader) }\end{array}$ & $\begin{array}{l}\text { Representatives from the } \\
\text { company group and the } \\
\text { production organisations: Factory } \\
\text { A and B. }\end{array}$ \\
& & $\begin{array}{l}\text { (Production management, } \\
\text { regional human resource } \\
\text { management, and eventually }\end{array}$ \\
& & team members)
\end{tabular}

The first step was an "initiation and anchoring" phase, where mutual insights and agreements for starting a co-operation were founded at top management level at the new firm as well as 
at relevant trade union organisations. The strategy was to anchor the process on a strategic level nationally, by creating a Central Working Council (at company level and trade union national level). Based on the commonly agreed Declaration of Purpose (DoP) for trade union collaboration, as described previously, the DoP was used when new people joined the collaboration process. It was also found appropriate to use in the extended process, when they proceeded further with expanding the stakeholder collaboration chain in regions for future factories, in alignment with the industrial start-up phases. When the new firm approached industrialisation phases, two Regional Working Councils were initiated on regional levels for the planned factories in different municipalities, in this case Factory $A$ and Factory B.

As the new firm further approached commissioning and industrialisation phases in the production plants, initiatives were taken to create local trade union working councils (within the new firm). In the expanding stakeholder collaboration process, the different levels of working councils worked in parallel, both vertically and horizontally, with the aim that the local working councils became drivers for realisation and further development of the trade union collaboration process and co-operated within relevant topics for the two factories.

The meeting structures were developed over time, and started with monthly meetings in the Central Working Council, which also combined them with benchmarking visits at two global companies. Gradually, when the Regional Working Councils were formed, they formalised the meeting structure with quarterly meetings for each Working Council and opportunities for transparency and joint large meetings in between. A challenge was the fast pace and complexity of the emerging new firm, and parallel work processes requiring attention, and representatives in the Working Councils developing roles and changing positions, both within the co-operation unit as well as among the trade union representatives.

Furthermore, initiatives were taken as the new firm's business proceeded with planned extended industrial establishment of factories in Europe. Additionally, the process leader organised several informal meetings where the purpose was to identify the new firm's needs and requirements as well as key actors among social partners with whom it was relevant to partner and to harmonise strategic approaches.

\section{The content: Approaches, co-operation topics and outcomes}

In general, at a central level, strategic topics were addressed, and as the new firm further developed and proceeded, operational topics were managed at the regional levels. The Regional Working Council for Factory A addressed topics regarding the test and industrialisation factory in one municipality, while the Regional Working Council for Factory B addressed issues regarding the forthcoming large-scale factory. However, these two factories were planned to be complementary; there were common topics for both working councils regarding design for production work organisation, roles, leadership, etc. An overview of co- 
operation topics during the Working Council meetings is categorised and exemplified according to the elements vital for sustainable development and long-term effects identified by Svensson and Brulin (2014), see Table 3.

Table 3. Extract of the new firm's approaches and topics in collaboration process with the trade union.

Thematic summary based on Svensson and Brulin (2014).

\begin{tabular}{|c|c|c|}
\hline \multicolumn{2}{|c|}{$\begin{array}{l}\text { Elements for sustainable } \\
\text { development }\end{array}$} & \multirow{2}{*}{$\begin{array}{l}\text { Extract of the new firm 's approaches and topics in } \\
\text { collaboration process with the trade union } \\
\text { Strategic sustainability focus } \\
\text { - Increased top management attention to dimensions of } \\
\text { sustainable work, part of social sustainability, in early } \\
\text { start-up phases }\end{array}$} \\
\hline \multirow{4}{*}{ 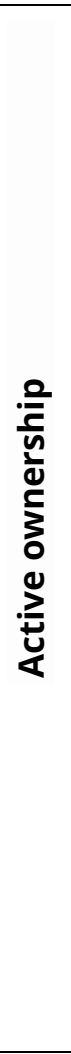 } & \multirow{2}{*}{$\begin{array}{l}\text { Prerequisites for } \\
\text { the creation of the } \\
\text { process: Resources, } \\
\text { governance, and } \\
\text { attention }\end{array}$} & \\
\hline & & $\begin{array}{l}\text { Project creation for the stakeholder collaboration process with } \\
\text { social partners } \\
\text { - Assigned process leader with a clear mission to create } \\
\text { relationships and fruitful co-operation with social } \\
\text { partners, } \\
\text { i.e., employer associations and relevant employee }\end{array}$ \\
\hline & \multirow[t]{2}{*}{$\begin{array}{l}\text { How results were } \\
\text { taken care of and } \\
\text { become part of the } \\
\text { regular business }\end{array}$} & $\begin{array}{l}\text { Forming flexible Collective Agreements (CA) } \\
\text { - Integration of prerequisites in a CA for the first factory, } \\
\text { suitable for the start-up firm's demands and } \\
\text { prerequisites, where high flexibility was needed }\end{array}$ \\
\hline & & $\begin{array}{l}\text { Structured working council process with common aim to rapidly } \\
\text { achieve drivers within the firm } \\
\text { - } \quad \text { Regular meetings and follow-ups both in-between and at } \\
\text { forthcoming meetings } \\
\text { - } \quad \text { Rapid roll-out also striving to create broad participation at } \\
\text { local workplaces } \\
\text { - Leadership requirements defined, serving as a base when } \\
\text { recruiting leadership positions }\end{array}$ \\
\hline \multirow{3}{*}{ 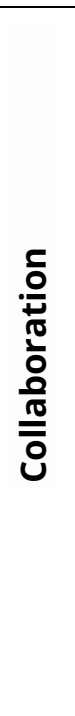 } & \multirow[t]{2}{*}{$\begin{array}{l}\text { Collaboration } \\
\text { between strategic } \\
\text { organisations for } \\
\text { development and } \\
\text { joint knowledge } \\
\text { creation }\end{array}$} & $\begin{array}{l}\text { Strategic anchoring at top management level and key functions } \\
\text { - Decision to start a process with intention to establish } \\
\text { fruitful collaboration with social partners, i.e., both } \\
\text { employee and employer organisations at national level } \\
\text { - Constantly anchoring activities carried out by the process } \\
\text { leader due to changes in the new firm's work } \\
\text { organisation with people changing positions }\end{array}$ \\
\hline & & $\begin{array}{l}\text { Invitation to relevant stakeholders } \\
\text { - Selection of representatives in the working councils who } \\
\text { preferably had experience of solution-oriented industrial } \\
\text { trade union collaborations }\end{array}$ \\
\hline & $\begin{array}{l}\text { Levels of } \\
\text { collaboration, } \\
\text { within and between } \\
\text { processes }\end{array}$ & $\begin{array}{l}\text { Agreement upon a "Declaration of Purpose for Collaboration } \\
\text { (DoP) } \\
\text { - A common agreement on purpose and aim for the new } \\
\text { firm's collaboration process with trade unions was }\end{array}$ \\
\hline
\end{tabular}




\begin{tabular}{|c|c|c|}
\hline & & $\begin{array}{l}\text { conducted and after review rounds clarified with work } \\
\text { environment topics } \\
\text { The DoP was utilised as a platform in the process and } \\
\text { used during introductions when new members entered } \\
\text { the working councils }\end{array}$ \\
\hline & & $\begin{array}{l}\text { A clear purpose, aim and priorities, and a systematic approach } \\
\text { - The process leader prepared and followed up each } \\
\text { meeting individually with each stakeholder }\end{array}$ \\
\hline & & $\begin{array}{l}\text { Continuous regional and local anchoring both within the new } \\
\text { fast-growing firm as well as with stakeholders in regions for } \\
\text { factory establishment } \\
\text { - } \quad \text { Preparation and further local anchoring activities and } \\
\text { refining collaboration structures for forthcoming Local } \\
\text { Working Councils within each factory and "headquarters" } \\
\text { - Invitation to start-up firm's employees to participate in } \\
\text { the trade union collaboration process }\end{array}$ \\
\hline \multirow{7}{*}{ 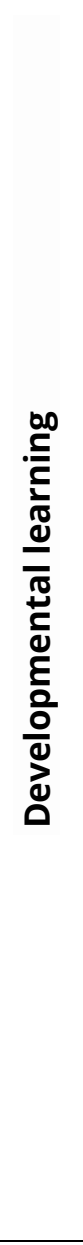 } & \multirow[t]{3}{*}{$\begin{array}{l}\text { Transparency and } \\
\text { communication }\end{array}$} & $\begin{array}{l}\text { Constant dialogue and information of actual state and obstacles } \\
\text { - Creating mutual understanding among all stakeholders of } \\
\text { employee work situation, prerequisites, and needs }\end{array}$ \\
\hline & & $\begin{array}{l}\text { Shared meeting minutes } \\
\text { - All working council meetings were documented and } \\
\text { shared }\end{array}$ \\
\hline & & $\begin{array}{l}\text { Open dialogue regarding new firm's and stakeholders' issues } \\
\text { - Examples: Dialogues of the reasons for membership in an } \\
\text { employer organisation, and if collective agreements for } \\
\text { the labour work was relevant }\end{array}$ \\
\hline & $\begin{array}{l}\text { Adaption to } \\
\text { changing } \\
\text { conditions }\end{array}$ & $\begin{array}{l}\text { Flexibility in collective agreements } \\
\text { - Decision to proceed with a flexible collective agreement } \\
\text { related to Factory B and the company group, based on } \\
\text { learnings from Factory A }\end{array}$ \\
\hline & \multirow[t]{3}{*}{$\begin{array}{l}\text { Learning } \\
\text { opportunities }\end{array}$} & $\begin{array}{l}\text { Benchmarking } \\
\text { - Benchmarking activities in strong global companies in the } \\
\text { region, and nationally }\end{array}$ \\
\hline & & $\begin{array}{l}\text { Solution orientation in the major greenfield project in a new } \\
\text { industrial domain } \\
\text { - A steep learning curve with opportunities for individual, } \\
\text { team and organisational learning } \\
\text { - Cross-border collaborations with broad employee } \\
\text { participation }\end{array}$ \\
\hline & & $\begin{array}{l}\text { Self-assessment of the collaboration process } \\
\text { - Assessment of the collaboration process in two "big } \\
\text { meetings" where all stakeholders participated }\end{array}$ \\
\hline
\end{tabular}

One main co-operation topic was collective agreements where the new firm had requirements to create and adapt agreements to the specific needs and requirements of a fast-growing industrial start-up. This was expressed by the CEO as:

«To succeed with our business mission, we need to create an agile work

organisation, enabling fast decisions, innovative solutions, and an attractive 
workplace with teams that can develop and deliver our products and solutions to customers worldwide. Thus, we need to develop collective agreements in cooperation with trade unions. »

There were discussions of the benefits and issues regarding collective agreements resulting in a common view that "collective agreements are designed to strengthen competitiveness and enable flexibility". For example, there were discussions on how collective agreements could be adapted, according to a new fast-growing firm's specific needs during its major industrial start-up (in comparison with established firms), with needs such as flexibility in working hours, work across organisational and functional borders, etc. It was also put forward that early development of collective agreements had the potential to reduce the risk of having a variety of agreements later on in an expanding organisation. This would require cooperation with many trade unions representing different professions, which would increase complexity and complicate decision-making. Furthermore, the new firm's branding opportunities were discussed, as it was assumed to strengthen the firm's attractiveness to talented employees. Also, as the multinational new firm had various experiences with trade union collaborations, anchoring approaches were needed in order to broaden the understanding of the national culture for the planned industrial establishment including the Nordic model related to work.

Other main co-operation topics were:

- Forthcoming production work organisation and work environment: Roles, shift structure, leadership criteria and support, work environment, individual's possibilities of role and career development. Specifically, roles and collaboration of direct (i.e., blue-collar), and indirect (white-collar) workers were discussed where the new firm had a need for strong co-operation and flexibility between functions, roles, and teams.

- Work environment: Working methods when everything is not in place, collaboration with subcontractors in construction and commissioning phases, how to speed up slow processes, employee mobility, managing workload peaks and demands, health and safety work, collaboration with external partners for occupational healthcare, security.

- Social sustainability in working life and private life: Approaches related to cultural differences and opportunities, equity, gender and age balance, the start-up firm's impact on society, social issues related to employees moving to a new country/city, housing, bureaucracy, regulations, work permits, etc.

- Skills and competences: Talent acquisition, recruitment, training of staff, competence development, competence validation systems, how to utilise learning opportunities within the new domain and the rapid learning curve.

- Structures: Leadership, communication strategy and support, policies related to drugs and alcohol, work permits, onboarding, and introduction programmes. 
- The new firm's trade union collaboration process itself: Roles, anchoring, how to efficiently and rapidly gain active local ownership aligned with the new firm's emerging development.

An outcome from the new firm's establishment of a "stakeholder collaboration chain" was also that the work served as a platform for the initial dialogue with trade unions in other countries, where a new council (the European working council) was planned to be created to focus on forthcoming establishment in other European countries. In the latter phase of the case study, there were early initiatives for an additional large-scale factory in a joint partnership in Europe, as well as additional assembly factories, and pilot plants for recycling.

\section{Discussion}

The aim of this paper was to explore why and how new firms can create relations and stakeholder collaboration with trade unions during industrial start-ups. The identified elements vital for sustainable development of change processes (i.e., active ownership, collaboration and developmental learning), as described by Svensson and Brulin (2014), are used as a lens for a thematic analysis and discussion in this paper, see Figure 1.

The case demonstrates a new firm's early phase of an industrial start-up, and is in this context viewed as a "change process" where the new firm initiated a collaboration process with external stakeholders, in particular trade unions. The new firm already had from the very first a clear sustainability strategy, initially focusing on economic and ecological dimensions of sustainability. Over time they also integrated social dimensions of sustainability related to work, and realised the potential to co-operate with social partners, in this case trade unions. They had a common vision of the collaboration in terms of both striving to achieve results (successful start-up), and to provide a good working environment (health, equality, competence development), a balance crucial for sustainable change processes (Elg et al., 2015). Moreover, to realise plans and go from "vision to action" it was crucial that this was part of the new firm's strategy, anchored at top management level, which was observed in the case. The international multicultural firm had employees with various experiences of trade union co-operation, which made it even more important that top management was clear and communicated the strategy and the motive for developing their own culture inspired by the Nordic model related to work (Garmann-Johnsen et al., 2018; Huzzard \& Nilsson, 2004).

Element of active ownership: One challenge to achieving active ownership in the collaboration process was the rapid development pace of the new firm, with impact on changes on the work organisation with people changing positions within the evolving organisation. Another challenge was that the fast-growing multinational firm had varied experiences with trade union collaborations. Lessons from the case were the role and actions of the experienced process leader with strong relations with social partners and industrial experience, as a driver and link between different levels and with all stakeholder representatives. However, there 
might be a risk of not gaining active ownership for a change process in a stakeholder chain if a process leadership role is not gradually integrated into the line organisation.

The regular and structured working council meetings were a way to identify prioritised cooperation areas, but the trust and relations created by way of the working council meetings were important for operationalisation in terms of joint activities and finding solutions together. The main outcome of jointly creating a collective agreement was designed according to the new firm's specific flexibility needs during the start-up, which was regarded as a unique approach, neither found in practice nor reported in literature.

This example illustrates how desired ambitions were transformed and integrated into practice, and became part of longer-term agreements considering stakeholders' needs, which eventually can be part of the firm's regular business and are crucial for sustainable change processes.

Element of collaboration: As the case context was an emerging fast-growing firm, there was a need to initiate collaboration at different levels and regions. There was also a need for a pace that aligned with the firm's industrial establishment process for new factories, and to constantly anchor and introduce new stakeholder representatives at different levels with complementary practitioner's knowledge, as stressed by (Totterdill et al., 2016). A useful platform for achieving consensus in the very early collaborative phases was the "Declaration of Purpose for Collaboration (DoP), but this was gradually replaced by increasingly structured descriptions of desired work processes. By addressing the need for work flexibility, rapid decision-making and working across borders, the initial collective agreements developed during the start-up phase have a potential to form a foundation for a co-operative culture in subsequent production organisations and to be adapted in future collective agreements when production is running. This also opens up opportunities to mitigate traditional boundaries between blue-collar and white-collar workers which in turn can contribute to increased flexibility and capability for solution-oriented work.

Element of developmental learning: The new firm was characterised by a high degree of uncertainty with challenges of developing structures due to its fast growth rate, as is commonly recognised in new ventures such as start-up environments (McKelvie et al., 2018). Another challenge is that a young entrepreneurial firm may initially lack internal competences to design and realise future plans, requiring co-operation with external stakeholders (Davila et al., 2010). In a multinational workplace, which was the makeup of the case company, another challenge in the new firm was various experiences with, and concepts of, trade union collaboration, as in literature described as both conflict- and solution-oriented (Geary \& Trif, 2011). On the other hand, the entrepreneurial mindset in the new firm was a driver for creation of innovative solutions. This mindset was also observed in the early trade union cooperation where new challenges and topics were raised with joint ambition to find new approaches and solutions, both in a short-term and long-term perspective. From a collaboration process perspective, it was also observed that these reflections at the working 
council meetings were means for individual and participating stakeholders developmental learning (Ellström, 2010; Svensson \& Brulin, 2014), with potential of further application in other change processes.

The stakeholder sustainability chain: As observed in the case study, a mutual understanding of stakeholders' prerequisites in an industrial start-up ecosystem were increasingly vital, when complexity increases during an industrial start-up over time. Neither of the participating trade union organisations had been part of such an industrial start-up process from scratch before. The normal procedure was to establish trade union co-operation first during operation phases in the factories when local trade union communities were in place, as stated in this case. However, they saw a great potential both for the start-up firm's mission as well as for job opportunities in the society and possibilities to contribute to concepts for future industrial workplaces, as well as job opportunities and society development.

From the new firm's perspective, as described above, the key business reasons and main arguments for creating relations and a structured collaboration process with trade unions in early development phases were opportunities:

- to "strategically build right from scratch" by co-operating with complementary competences enabling utilisation of learnings of success factors from other industrial development processes and start-ups,

- to proactively manage potential obstacles, as complexity with influencing factors and costly countermeasures increases over time,

- to create an agile work organisation enabling fast decisions, innovative solutions with healthy and attractive industrial work and workplaces, enablers for competitive advantages of the new firm and industrial start-up, and

- to develop a desired leadership culture and develop structures and prerequisites for employer and employee participation in improvement and development work with the Nordic model as a role model for the company group's culture.

From a trade union perspective on the other hand, the main arguments for early co-operation with a new start-up firm were:

- the unique possibility to be involved in a new firm's development within a new industrial domain,

- to jointly support the possibilities for successful establishment of new factories, and

- to contribute to development of concepts for future manufacturing sites, as well as achieving useful learnings for other industrial development processes and start-ups.

Learnings from the case were also that early co-operation in a stakeholder chain with trade unions based on the Nordic model related to work, has potential to contribute to identification of prerequisites needed to consider during a planned industrial establishment 
in a region, both regarding forthcoming employees' working conditions in the firm as well as conditions outside work (housing, schools, culture, etc.).

Furthermore, if the stakeholder community is characterised by trust, (Levinson, 2008), it has the potential for development of proactive and reactive approaches in a dynamic, fastchanging work environment. Hence a balance between flexibility and stability in an increasingly uncertain world is needed, as proposed by Kjellberg (2011), where this study highlights a potential for new firms to develop collaboration with trade unions during industrial start-ups and the new firm's early development phases.

\section{Conclusion}

This case study shows potential for new firms to create relations and co-operation at an early stage with social partners such as trade unions, as it enables proactive approaches on social dimensions of sustainability related to work. New firms and industrial start-up phases represent a constantly moving work environment with fast changes and uncertainties, which requires co-operation in a stakeholder chain characterised by a clear purpose for collaboration, trust, mutual understanding of specific prerequisites, and solution-oriented approaches. Collaboration processes need to meet both a new emerging firm's development demands and future employees' individual prerequisites and needs. Through a new firm's early stakeholder co-operation with trade unions, the case also shows that it has potential for positive outcomes on flexibility, which is important for the success of a new firm's establishment, growth, and industrial start-up, as well as social sustainability both related to work and for society. However, a systematic approach is needed with anchoring activities, both within and between the new firm and external stakeholders such as trade unions at national, regional and local levels. This includes a common vision with a clear purpose for the collaboration, regular meetings to enable trustful relations, thorough understanding, and flexible conditions during the fast development of a new firm, with employees' work roles changing quickly.

A theoretical contribution of this paper is the elaboration of elements, which constitute mechanisms for sustainable development, as described by Svensson and Brulin (2014), in a context of change processes such as industrial start-ups carried out in new firms. Practical implications are how new firms can initiate and establish co-operation with trade unions and other social partners in fast-moving work environments and change processes. This provides opportunities to proactively integrate dimensions of sustainability work, as well as other social sustainability factors vital for new firms in early development phases and industrial start-ups, hence avoiding potential future obstacles and instead creating opportunities for benefits both from an individual and business perspective.

Serendipity from the findings includes co-operation processes related to competence acquisition, and societal development needed to meet both a new emerging firm's and future employees' individual prerequisites and needs. Hence, a new firm building a 
stakeholder collaboration chain with trade unions inspired by the Nordic model enables increased attention to dimensions of social sustainability that need to be aligned and integrated with parallel work processes in early development phases of a new firm, which is also beneficial from a societal perspective.

\section{Acknowledgements}

We thank the participating company, the funding organisation Vinnova, the Swedish Governmental Agency for Innovation Systems, RISE Research Institutes of Sweden, and HELIX Competence Centre at Linköping University for enabling this research. Additional funding provided by the XPRES (Initiative for Excellence in Production Research) and valuable reviewer comments are also gratefully acknowledged.

\section{References}

Akehurst, G., Comeche, J. M., \& Galindo, M. A. (2009). Job satisfaction and commitment in the entrepreneurial SME. Small Business Economics, 32(3), 277-289. https://doi.org/10.1007/s11187-008-9116-z

Audretsch, D. B., Aldridge, T. T., \& Sanders, M. (2011). Social capital building and new business formation: A case study in Silicon Valley. International Small Business Journal, 29(2), 152-169. https://doi.org/https://doi.org/10.1177/0266242610391939

Bank, N., Fichter, K., \& Klofsten, M. (2017). Sustainability-profiled incubators and securing the inflow of tenants The case of Green Garage Berlin. Journal of Cleaner Production, 157, 76-83. https://doi.org/10.1016/j.jclepro.2017.04.123

Beer, M., Eisenstat, R. A., \& Spector, B. (1990). The critical path to corporate renewal. Harvard Business Press. Boston, MA

Brulin, G., \& Svensson, L. (2016). Managing sustainable development programmes: A learning approach to change. Routledge. London and New York. https://doi.org/10.4324/9781315593647

Davila, A., Foster, G., \& Jia, N. (2010). Building sustainable high-growth startup companies: Management systems as an accelerator. California Management Review, 52(3), 79-105. https://doi.org/https://doi.org/10.1525/cmr.2010.52.3.79

DiVito, L., \& Ingen-Housz, Z. (2019). From individual sustainability orientations to collective sustainability innovation and sustainable entrepreneurial ecosystems. Small Business Economics. https://doi.org/10.1007/s11187-019-00254-6

Elfring, T. \& Hulsink, W. (2003). Networks in entrepreneurship: The case of high-technology firms. Small business economics, 21/4), 409-422. https://doi.org/10.1023/a:1026180418357

Elg, M., Ellström, P.-E., Klofsten, M., \& Tillmar, M. (Eds.). (2015). Sustainable development in organizations: Studies on Innovative Practices,1-13. Edward Elgar Publishing, Cheltenham, UK. https://doi.org/10.1023/a:1026180418357

Ellström, P.-E. (2010). Practice-based innovation: a learning perspective. The Journal of Workplace Learning, 22 (1-2), 27-40. https://doi.org/10.1108/13665621011012834

Ellström, P.-E., Elg, M., Wallo, A., Berglund, M., \& Kock, H. (2020). Interactive Research: Concepts, Contributions, and Challenges. Journal of Manufacturing Technology Management, 31(8), 1517-1537. https://doi.org/10.1108/jmtm-09-2018-0304

Garmann-Johnsen, N. F., Helmersen, M., \& Eikebrokk, T. R. (2018). Worklife Ergonomics in Digital Co-Creation: The 'What', the 'Why'and the 'How'. European Journal of Workplace Innovation, 4(1), 55-77. https://doi.org/10.46364/ejwi.v4i1.503

Geary, J., \& Trif, A. (2011). Workplace partnership and the balance of advantage: A critical case analysis. British Journal of Industrial Relations, 49, s44-s69. https://doi.org/10.1111/j.1467-8543.2010.00827.x 
Glover, L., Tregaskis, O., \& Butler, P. (2014). Mutual gains? The workers' verdict: a longitudinal study. The International Journal of Human Resource Management, 25(6), 895-914. https://doi.org/10.1080/09585192.2012.743479

Harlin, U., \& Berglund, M. (2020). Designing for sustainable work during industrial startups—the case of a highgrowth entrepreneurial firm. Small Business Economics. https://doi.org/10.1007/s11187-020-00383-3

Hasle, P. (2014). Development of sustainable work-is there a future for a Nordic model. Proceedings of the ODAM/NES congress, Ergonomics challenges in new economics, Copenhague, Denmark

Hilsen, A. I., \& Kværne, T. (2020). Industrial action research: the Norwegian way. European Journal of Workplace Innovation, 5(2), 31-45.

Huzzard, T., \& Nilsson, T. (2004). Dancing queen? Partnership, codetermination and strategic unionism in Sweden. Strategic unionism and partnership: Boxing or dancing, 86-106. Palgrave Macmillan, Houndmills, UK https://doi.org/10.1353/lab.2006.0002

Johansson, J. and L. Abrahamsson (2009). The good work-a Swedish trade union vision in the shadow of lean production. Applied Ergonomics. 40(4): 775-780. https://doi.org/10.1016/j.apergo.2008.08.001

Kjellberg, A. (2011). Arbetsmiljön: det arbetssociologiska perspektivet. In Arbetsmiljön ur tre perspektiv. Lunds universitet

Klofsten, M., \& Lundmark, E. (2014). Att stimulera entreprenörskap och lärande hos nya entreprenörer : Ett praktikfall. In K. Henrik (Ed.), Lärande i arbetslivet : möjligheter och utmaningar : en vänbok till Per-Erik Ellström (pp. 198-212). Linköpings universitet. http://doi.org/10.3384/lic.diva-130605

Kohler, T. (2016). Corporate accelerators: Building bridges between corporations and startups. Business Horizons, 59(3), 347-357. https://doi.org/https://doi.org/10.1016/j.bushor.2016.01.008

Levinson, K., \& Wallenberg, J. (2006). Partssamverkan i offentlig verksamhet - en undersökning av svensk ledningsmodell i förändring. Arbetsliv i omvandling. 7, 1-39.

Levinson, K. (2008). Partssamverkan i förändring-en jämförelse mellan privat och offentlig sektor. Arbetsliv i omvandling. 1, 44-59.

March, J. G. (1981). "Footnotes to organizational change." Administrative Science Quarterly: 26, 563-577.

McKelvie, A., Wiklund, J., \& Brattström, A. (2018). Externally acquired or internally generated? Knowledge development and perceived environmental dynamism in new venture innovation. Entrepreneurship Theory and Practice. 42(1), 24-46. https://doi.org/https://doi.org/10.1177/1042258717747056

Nielsen, K. A., \& Svensson, L. (2006). Action research and interactive research: beyond practice and theory. Shaker publishing. Maastricht, Netherland

Nielsen, P., Nielsen, R. N., Bamberger, S. G., Stamhus, J., Fonager, K., Larsen, A., Vinding, A. L., Ryom, P., \& Omland, $\varnothing$. (2012). Capabilities for innovation: The Nordic model and employee participation. Nordic journal of working life studies, 2(4), 85. https://doi.org/10.19154/njwls.v2i4.2306

Pettigrew, A. M. (2012). Context and action in the transformation of the firm: A reprise. Journal of Management Studies, 49(7), 1304-1328. https://doi.org/10.1111/j.1467-6486.2012.01054.x

Rydell, A. (2015). Partssamverkan i nedläggningsprocesser. Arbetsmarknad \& Arbetsliv, 21(1), 39-53.

Sarfati, H. (2014). Nordic Lights-Work, Management and Welfare in Scandinavia, In A. Sandberg (Ed.), Relations Industrielles/Industrial Relations, 69(1), 229-232. SNS Förlag, Stockholm. https://doi.org/10.7202/1024218ar

Smedlund, A. (2006). The roles of intermediaries in a regional knowledge system. Journal of Intellectual Capital. 7 (2) 204-220. https://doi.org/10.1108/14691930610661863

Svensson, L., \& Brulin, G. (2014). Lärande som drivkraft och för utveckling. In K. Henrik (Ed.), Lärande i arbetslivet : möjligheter och utmaningar : en vänbok till Per-Erik Ellström (pp. 279-292). Linköpings universitet, Linköping.

Svensson, L., Brulin, G., Jansson, S., \& Sjöberg, K. (2013). Att fånga effekter: av program och projekt. Studentlitteratur, Lund.

Svensson, L., Ellström, P.-E., \& Brulin, G. (2007). Introduction - in interactive research. International Journal of Action Research, 3(3), 233-249.

Totterdill, P. (2015). Closing the gap: The fifth element and workplace innovation. European Journal of Workplace Innovation, (1), 55-74. https://doi.org/10.46364/ejwi.v1i1.166

Totterdill, P., Exton, O., Exton, R., \& Gold, M. (2016). High-performance work practices in Europe: Challenges of diffusion. European Journal of Workplace Innovation, 2(1), 63-81. https://doi.org/10.46364/ejwi.v2i1.355

Tripathi, N., Seppänen, P., Boominathan, G., Oivo, M., \& Liukkunen, K. (2019). Insights into startup ecosystems through exploration of multi-vocal literature. Information and Software Technology, 105, 56-77. https://doi.org/10.1016/j.infsof.2018.08.005 
Vallance, S., Perkins, H. C., \& Dixon, J. E. (2011). What is social sustainability? A clarification of concepts. Geoforum, 42(3), 342-348. https://doi.org/doi:10.1016/j.geoforum.2011.01.002

Volkmann, C., Fichter, K., Klofsten, M., \& Audretsch, D. B. (2019). Sustainable entrepreneurial ecosystems: an emerging field of research. Small Business Economics. https://doi.org/10.1007/s11187-019-00253-7

Zellman, E., \& Kemp, S. (2004). Estimating the Other Party's Preferences and Trust in Trade Union and Employer Negotiations: A Comparison between NZ and Sweden. New Zealand Journal of Employment Relations, 29(2), 17-31

\section{About the authors}

Ulrika Harlin, MSc/LicEng, is an industrial researcher at RISE Research Institutes of Sweden. She holds a Licentiate of Engineering in Human Factors Engineering at Chalmers University and a M.Sc. in production system development. She is the co-ordinator of the Swedish network for workplace-related R\&D for sustainable working life, AFoU, and the co-ordinator of the Production Management Cluster, part of The Swedish Manufacturing R\&D Clusters.

Martina Berglund, PhD., is Assistant professor at the Division of Logistics and Quality Management, Department of Management and Engineering at Linköping University. She is the director of the Human Factors Network in Sweden and a co-ordinator at HELIX Competence Centre at Linköping University

Katrin Skagert is a researcher at RISE Research Institutes of Sweden. She holds a PhD. in Public health and community medicine and a BSc in HRM at University of Gothenburg.

Mattias Elg is Professor of Quality Technology and Management, Linköping University, Sweden. He is also centre director at HELIX Competence Centre, Linköping University. 